$\mathrm{T}$ eenagers can do terrible things. In 1999, Kuntrell Jackson, then 14, was walking with his cousin and a friend in Blytheville, Arkansas, when they decided to rob a local video store. On the way there, his friend, Derrick Shields, revealed that he was carrying a sawn-off shotgun in his coat sleeve. During the robbery, Shields shot a shop worker in the face, killing her.

Four years later, 14-year-old Evan Miller and an older friend were getting drunk and stoned with a middle-aged neighbour in a trailer park in Moulton, Alabama. A fight broke out, and Miller and the friend beat the neighbour with a baseball bat. Then they set fire to his home and ran, leaving him to die.

Both Miller and Jackson were found guilty of homicide and sentenced to life without parole, meaning that both will spend the rest of their lives in prison. They are not alone. The United States currently has more than 2,500 individuals serving such sentences for crimes they committed as juveniles - that is, before their eighteenth birthdays. It is the only country that officially punishes juveniles in this way. Both Miller and Jackson appealed, arguing that their immaturity at the time of the crime rendered them less culpable for their actions than adults, and that they deserved a less severe punishment. The Supreme Court heard arguments in Miller v. Alabama and Jackson v. Hobbs in March, and is expected to deliver its ruling by this summer.

The cases are notable not only because they could abolish life-without-parole sentences for juveniles, but also because neuroscience research may play a part in the decision. Several organizations submitted briefs to the court detailing the growing body of research showing that the brain's development continues into at least the early twenties. This, they argue, may explain why young people are more impulsive than adults, more readily swayed by their peers and less likely to consider the consequences of their actions.

\section{UNDER THE INFLUENCE}

Advocates for juveniles have been embracing this work as part of a long-term strategy to ensure that young criminals are given less punishment than adults and more opportunities for rehabilitation. And many neuroscientists studying the adolescent brain are gratified that their work is contributing to these efforts. "It's so satisfying to think that maybe in some minuscule way my work was relevant to society," says Bea Luna, who studies adolescent brain development at the University of Pittsburgh in Pennsylvania.

But the brain research may not have as great an influence in court as some scientists and advocates like to think. Some say that the neuroscience offers no fresh insight into adolescent behaviour, and may serve merely as a rhetorical flourish in judges' opinions or as a tool that lawyers and advocates exploit to make their case.
"The neuroscience is being used for an advocacy position," says Emily Murphy of Stanford University in California, who was a fellow with the MacArthur Foundation's Law and Neuroscience Project. "That's all it's always been, in a legal context." Murphy and others worry that the neuroscience currently being used in court may be abused, and might overshadow other research that could make a deeper impact on juvenile crime and punishment.

Historically, courts in the United States have treated juveniles with leniency. But in the late 1980 s and early 1990s, a rise in violent youth crime, including several high-profile school shootings, provoked a backlash of tough

\section{ATEENAGER IS LIKE ACAR WITH A GREAT ACCELERATORBUT TERRIBLE BRAKES.}

justice. Across the country, young offenders were increasingly transferred from the juvenile courts, which emphasize rehabilitation, to adult criminal courts, which focus on retribution and punishment, including the death penalty.

Advocates for juveniles have fought to reverse this trend, and have done so, in part, by pointing at major changes now known to take place in the adolescent brain. During maturation, the brain undergoes large-scale structural changes. Fatty tissue called myelin wraps around neurons, speeding up signal transmission in brain cells, particularly between brain regions. At the same time, superfluous connections are pruned away in a process that may decrease noise in the system and allow remaining neurons to function more efficiently.

These processes were once assumed to be completed during childhood, but techniques developed over the past two decades have shattered that idea. Structural magnetic resonance imaging (MRI) shows that pruning goes on into early adulthood. Diffusion tension imaging, another form of MRI, shows much the same for myelination. And functional MRI (fMRI), which reveals activity in the brain in near real time, has shown how this ongoing development affects activity levels in different parts of the brain. Some of the most marked changes during these later developmental periods occur in brain systems associated with impulse control ${ }^{1,2}$, resisting immediate rewards $s^{3}$ and emotional processing ${ }^{4,5}$ - all behaviours relevant to criminal activity.

Systems involved in processing reward also seem to mature more quickly than those involved in decision-making and impulse control. One fMRI study ${ }^{6}$ showed that when adolescents were presented with rewards for performing a simple task, the nucleus accumbens - part of the brain's reward system - lit up in a pattern similar to that seen in adults in the study, but much more strongly. Meanwhile, the sparse activity seen in the prefrontal cortex - a region thought to be involved in decision-making and impulse control - looked more akin to that of children. The authors of the study say that this may help to explain the heightened risk-taking behaviour common in adolescents. A teenager, as advocates and some scientists like to say, is like a car with a great accelerator but terrible brakes. As Larry Steinberg, a psychologist who studies teen behaviour at Temple University in Philadelphia, Pennsylvania, has said, "With powerful impulses under poor control, the likely result is a crash".

\section{CRIME AND PUNISHMENT}

The Supreme Court got its first taste of this research in 2005, when it considered Roper v. Simmons. In 1994, Christopher Simmons was sentenced to death in Missouri after he and an accomplice wrapped a woman's head in duct tape, bound her limbs with electrical wire, and threw her off a railway bridge. He was 17 at the time of the crime. When the case reached the Supreme Court, the American Medical Association (AMA) and American Psychological Association (APA) filed briefs in Simmons's support explaining the current state of research on the immaturity of adolescent brains.

The court found it unconstitutional to impose the death penalty for crimes committed by juveniles; Simmons is now serving life without parole. Although the neuroscience evidence was never directly cited, Justice Anthony Kennedy wrote in the majority opinion that "as any parent knows and as the scientific and sociological studies ... tend to confirm, '[a] lack of maturity and an underdeveloped sense of responsibility are found in youth more often than in adults"'.

Many scientists and advocates for juveniles considered the result a triumph for neuroscience in the court, likening it to Brown v. Board of Education of Topeka, the landmark 1954 ruling that ended racial segregation in public schools. Brown v. Board was believed to be heavily influenced by a sociological study of children judging dolls of different colours. This purportedly showed that segregation had a negative impact on black students' self-esteem. Just as that case is thought to mark the modern era of the court's use of scientific research, Roper v. Simmons was believed to herald the era of neuroscience in the court.

Emboldened by the Roper decision, advocates and attorneys have increasingly called on neuroscience research when arguing that juveniles should be spared the harshest punishments. In 2010, the court ruled in Graham v. Florida that sentencing a juvenile to life without parole for a crime other than homicide was "cruel and unusual". The neuroscience 
research, emphasized in briefs from the AMA, the APA and Graham's lawyers, seemed to strike even more of a chord with the justices, who wrote in the majority opinion that "developments in psychology and brain science continue to show fundamental differences between juvenile and adult minds".

\section{BRAIN OVERCLAIM}

But some researchers are uncomfortable with the way this research is being used in the criminal justice system. There is certainly a correlation between brain development and behavioural maturity, but saying that observed differences in the adolescent brain cause certain adolescent behaviours is a symptom of what lawyer and psychologist Stephen J. Morse at the University of Pennsylvania in Philadelphia calls "brain overclaim syndrome". Neuroscientists, says Morse, are "always using language that suggests causation, when they don't know causation".

Moreover, the behaviours studied in the lab bear little resemblance to criminal behaviour. Scientists cannot perform brain imaging on someone in the process of committing a crime. Instead, they study volunteers who are challenged to resist impulses or follow rules. In some experiments looking to assess impulse control, for example, volunteers are told not to look at a flashing light. Not looking at the light, says Luna, who has used the task for more than ten years, "is extremely difficult to do. We know exactly what brain circuitry gets engaged to stop that reflexive response. Is it the same as murdering someone? No." But Luna argues that such experiments are relevant. Although adolescents can stop themselves from looking at the light, doing so is associated with much more activation of their prefrontal cortex than is seen in adults, suggesting that it is more difficult for them to control their impulses ${ }^{7}$.

But that wasn't really in question. Decades' worth of behavioural research had already established that teenagers take greater risks, are more driven by emotions and peer influence, and generally behave less responsibly than adults. Still, advocates say, neuroscience bolsters the arguments. "When you come up with a biological mechanism, it gives it a lot more credibility," says Luna. To many audiences, neuroscience evidence tends to be more convincing than behavioural science, particularly when aided by pictures of brain areas lighting up.

"Lawyers and judges have grown up thinking that social science is soft," says constitutional law scholar David Faigman at the University of California Hastings College of the Law in San Francisco. "Neuroscience gives the courts a hook." But, Morse says, treating neuroscience data as somehow harder than behavioural data is logically flawed. The neuroscience is only relevant to the law when it connects with behaviour. "If the psychology is soft, the neuroscience is soft," Morse says.

Hard or soft, the data are open to interpretation. And scientists have little control over when or how their research is used as a persuasive tool. Steinberg's research was cited in the court's opinion in Roper v. Simmons and in briefs in support of juveniles for Graham v. Florida and the two current cases - but it has also been used by advocates seeking to restrict the rights

\section{JUDGES MAY USE SCIENCE FOR RHETORICAL LEVERAGE, BUT SCIENCE RARELY, IF EVER, DRIVESA COURT DECISION.}

of adolescents, in particular the right to have an abortion without parental permission.

Ultimately, the neuroscience data can only take legal arguments so far. Juveniles may be less responsible than adults, but they may still be responsible enough to deserve the same punishment for similar crimes, says Morse. "That's not a scientific question. It's a moral question, and, ultimately, a legal question." Because of this incompatibility, Faigman says that science rarely, if ever, drives a court decision. Judges may use science for rhetorical leverage when writing the opinion, but "it's not always clear whether the research made an impact".

\section{HOT HEADS OR COLD BLOODED}

Take Roper v. Simmons. Briefs to the court supporting Simmons presented scientific evidence that the immature brains of adolescents like him render them more likely to act in the heat of the moment, giving little thought to the future. But Simmons didn't fit that description: according to Supreme Court documents, he told his friends that he "wanted to murder someone" days before the murder, "by breaking and entering, tying up a victim, and throwing the victim off a bridge".

Although the court alluded to scientific research in its opinion, that research may not have influenced the decision. "The justices may have [already] come to the conclusion that the death penalty was fundamentally flawed, at least in its application to juveniles," says Faigman. "They needed to support that with good reasons."

If science's part in Roper v. Simmons was merely as a makeweight, then comparing it to Brown v. Board might not be far off the mark. In that case, Faigman says, the court had probably already decided to end segregation in public schools on moral and social grounds. Although "the perception was that science lay at the core of the decision", says Faigman, the doll study had been "severely criticized" before the ruling. It was only mentioned in a footnote.

When the court decides on Miller v. Alabama and Jackson v. Hobbs, advocates for juveniles hope to see life without parole taken off the table for all juveniles. But the court may draw the line at 14, the age of the petitioners. Whatever line the justices do draw, if they draw one at all, it will probably be based on legal and moral ideas rather than scientific evidence.

So does neuroscience deserve a place at the table? Perhaps, says Terry Maroney of Vanderbilt University Law School in Nashville, Tennessee, but it shouldn't outshine other evidence. Solid research by social scientists shows, for example, the high potential of teen criminals to reform, the inability of life sentences to deter juvenile crime, and racial inequalities in life-without-parole sentencing ${ }^{8}$. Focusing on biology draws attention away from socioeconomic, educational and cultural drivers of criminal behaviour. After all, most teenagers do not commit murder, despite their fledgling frontal cortices.

Evan Miller grew up with physical and emotional abuse so severe that he attempted suicide several times, starting at the age of five. He was using drugs and alcohol regularly before he was a teenager; the man he killed was his mother's drug dealer. Kuntrell Jackson was raised in the lap of violence. Bryan Stevenson, his attorney, told the Supreme Court justices that "his grandmother shot his uncle. His mother shot a neighbour. His brother shot someone. They were all put to jail."

Neuroscience supports what centuries of casual observation have strongly suggested: teenagers tend to be more impulsive and irresponsible than adults. That probably can't be changed, but the environments that they grow up in can be addressed with social policy. "That's harder," says Maroney. "It requires more work and sacrifice. It's easier to look and say, 'Ooh, look what's going on inside their heads! It's all their problem."' -

Lizzie Buchen is a freelance reporter in San Francisco and volunteers with prisoners at San Quentin State Prison.

1. Liston, C. et al. Cereb. Cortex 16, 553-560 (2006).

2. Velanova, K., Wheeler, M. E. \& Luna, B. Cereb. Cortex 18, 2505-2522 (2008).

3. Olson, E. A. et al. J. Cogn. Neurosci. 21, 1406-1421 (2009).

4. Burnett, S., Bird, G., Moll, J., Frith, C. \& Blakemore S.-J. J. Cogn. Neurosci. 21, 1736-1750 (2009).

5. Hare, T. A. et al. Biol. Psychiatry 63, 927-934 (2008).

6. Galvan, A. et al. J. Neurosci. 26, 6885-6892 (2006).

7. Luna, B. et al. Neurolmage 13, 786-793 (2001).

8. Nellis, A. The Lives of Juvenile Lifers (The Sentencing Project, 2012) 